\title{
Color Stability of Silicone or Acrylic Denture Liners: An in Vitro Investigation
}

\author{
Gulfem Erguna, DDS, PhD \\ Isil Cekic Nagas ${ }^{b}$ DDS
}

\begin{abstract}
Objectives: The aim of this study was to compare the color stability of three acrylic based hard liners (Ufi gel hard, Dura-Liner II, Tokuso Rebase) and two silicone based soft liners (Ufi gel permanent, Molloplast B) by using the colorimeter.

Methods: Sixty disc-shaped samples, with uniform size of $10 \mathrm{~mm}$ diameter and $2 \mathrm{~mm}$ in thickness were fabricated for each material. Thirty samples were made as control group in distilled water and the remaining thirty samples were weathered in accelerated aging chamber. Color measurements were made before and after distilled water and aging. Data were statistically analyzed using nonparametric Kruskal-Wallis and Mann-Whitney $\mathrm{U}$ tests.

Results: Data showed that there are significant differences among materials in both after distilled water and aging treatments $(P<.001)$. These results indicated that the most discolored liner material was Dura Liner II after aging $\left(\Delta E^{*}=16.30\right)$ and the least discolored material was Ufi gel permanent after distilled water $\left(\Delta \mathrm{E}^{*}=0.41\right)$.

Conclusions: Based on the results of this study, silicone based liner materials are considered to be more color stable than acrylic based liner materials. (Eur J Dent 2007;1:144-151)
\end{abstract}

Key words: Silicone; Acrylic liners; Color stability.

\section{INTRODUCTION}

Denture lining materials are widely used for the base of a denture to reduce pain or to improve the fit between the denture and mucous membrane. ${ }^{1}$ They act as a cushion and provide an even distribution of functional load onto the stress-bearing mucosa. ${ }^{2}$ Application of a soft lining material to the dentures can also increase the patient's masticatory performance, biting force and improve the chewing rhythm. ${ }^{3}$

Denture lining materials can be classified

- Associate Professor, Department of Prosthodontics, Faculty of Dentistry, Gazi University, Ankara, Türkiye

b Research Assistant, Department of Prosthodontics, Faculty of Dentistry, Gazi University, Ankara, Türkiye

- Corresponding Author: Dr. Gulfem Ergun Address: Süslü sok. 14/9Tandoḡan/Ankara 06580 Türkiye Tel.: +903122139701 Fax: +9031222392 26 E-mail : gulfemagazi.edu.tr, ergungulfemdyahoo.com as provisional or permanent, silicone rubber or acrylic resin, and can be either chemically or heat polymerized. ${ }^{4}$ A provisional liner is the one used intraorally for up to 30 days and a long-term liner is categorized as the one that maintains its softness and elasticity for more than 30 days. ${ }^{5}$ Furthermore, in a study, a long term liner was classified to be the one used for 1 year or longer. ${ }^{6}$ Silicone based lining materials are basically dimethylsiloxane polymers and do not contain plasticizer to produce softening effect. ${ }^{7}$ These lining materials are hydrophobic; this reduces water sorption, but simultaneously inhibits good affinity to the supporting tissues. ${ }^{8}$ Acrylic based lining materials are composed of the powder consisting of a higher methacrylate polymer lusually poly ethyl methacrylate) and a liquid of a higher methacrylate monomer (e.g. ethyl, n-butyl), in addition a plasticizer, commonly a phythalate..$^{9,10}$ When im- 
mersed in water, these materials undergo 2 processes; leaching of plasticizers and other soluble materials into water and water imbibition by the polymer. Eventually, the physical and mechanical properties of the materials change with time in the patient's mouth. ${ }^{9}$

An ideal processed denture liner should be resistant to imbibing oral fluids or releasing compounds into the saliva. High water sorption and solubility of lining material decrease mechanical properties such as hardness, transverse strength and fatigue limit. Discoloration, dimensional change and separation from a denture base can also appear because of the high values of sorption and solubility parameters. ${ }^{3,11}$ Thus, sorption, solubility and discoloration properties are important to evaluate the longevity of a liner. ${ }^{6}$

Denture relining materials often show changes in mechanical properties with aging. ${ }^{12}$ Their longevity was evaluated by immersion in water, accelerated weather testing and thermocycling. ${ }^{13-16}$ The use of accelerated aging process has increased in dental researches recently. ${ }^{17-20}$ This process simulates the effects of long-term exposure to environmental conditions through an accelerated weathering process that involves ultraviolet light exposure, temperature and humidity changes. ${ }^{21}$ Besides, previous studies have shown the effect of accelerated aging on the physical and mechanical properties of the liner materials. ${ }^{12,22}$

Color stability is an important property of a denture liner to retain its color in specified environment, especially in long term use. Besides, color assessment and its reproduction is one of the most challenging aspects of dentistry. ${ }^{23}$ Visual color matching is still the primary method for evaluating the color and may cause dissatisfying results. ${ }^{20,24}$ Photoelectric tristimulus colorimeters have the potential to remove some of the variables found when the visual method is used exclusively and provide accurate and repeatable measurements. ${ }^{25,26}$

Color changes in the oral environment need to be investigated further in order to predict which materials will provide the best clinical service in long term use. According to ANSI/ADA Specification No. 12, the denture liner should pass the color stability test, which requires that the specimen show no more than a slight color change after an exposure of 24 hours. ${ }^{27}$
This requirement might be difficult to achieve because most of the liners show noticeable color changes when exposed to ultraviolet light. ${ }^{28}$ Hence, the purpose of this in vitro study was to compare the effect of accelerated aging on the color stability of silicone and acrylic denture liners by using a colorimeter.

\section{MATERIALS AND METHODS}

Two silicone and three acrylic based lining materials used in this study are listed in Table 1. Sixty disc-shaped samples, with uniform size of $10 \mathrm{~mm}$ diameter and $2 \mathrm{~mm}$ in thickness, were prepared for each lining material according to the manufacturers' instructions. All of the samples were stored in distilled water (DW) at $37 \pm 1^{\circ} \mathrm{C}$ for 24 hours before color measurement.

Six samples from each tested liner material served as control groups and these samples were immersed in DW at $37 \pm 1^{\circ} \mathrm{C}$ in a dark room for 900 hours. The remaining 6 samples from each group were subjected to accelerated aging in WheatherOmeter instrument (QUV accelerated Weathering Tester, The Q-Panel Company 26200 First St., SN: 92-7475-44, Cleveland, Ohio, USA.) and exposed to continuous ultraviolet and visible-light, at a temperature of $110^{\circ} \mathrm{F}$ and intermittent DW spray was used for a period of 18 minutes within each 2-hours period. The manufacturer of the weathering instrument estimates that 300 hours of aging intraorally is equivalent to 1 year of clinical service. ${ }^{17,29}$ The samples were kept for 900 hours either in weathering machine or immersed in DW (equal to 3 years of service).

Before and after either aging or immersion in DW, color measurements of the samples were evaluated with the colorimeter (Spectrometer, Gretag Machbeth, SN: KH 1435, Regensdolf, Switzerland). Before each measurement session, the colorimeter was calibrated with its white reference tile according the manufacturer's instructions. The same examiner made three measurements for each sample.

The color change values of all samples were calculated by measuring the mean and standard deviation of $\triangle E^{*}$ values with the use of CIELAB color system..$^{20,30}$ The critical remark of color change $\left(\Delta E^{*}\right)$ were quantified by The National Bureau of Standards (NBS) rates the way that a color change is evaluated by the human eye (Table 2). As such, 
the color change values of all liner materials were multiplied by a factor of 0.92 to obtain the NBS values. ${ }^{22,31}$

A Kruskal-Wallis, nonparametric one-way analysis of variance (ANOVA) followed by a multiple comparisons test were used to analyze the k-independent group of data from this investigation. In addition, for two-independent samples comparisons Mann-Whitney $U$ tests were used. All analyses were computed with the SPSS for Windows 11.00 (SPSS Inc., Chicago, IL., USA).

\section{RESULTS}

The mean color measurements ( $L^{*}, a^{*}$, and $b^{*}$ ) of five liner materials recorded from the colorim- eter are given in Table 3. The mean and standard deviation of color change $\left(\Delta E^{*}\right)$ values and their corresponding NBS values after subjecting them to DW and aging are shown in Table 4. The discoloration occurred after aging was significant when compared to the control samples stored in DW lexcept UH).

The highest discoloration in all conditions was apparent with $\mathrm{DL}\left(\Delta \mathrm{E}^{*}{ }_{\text {Aging }}=16.30\right)$ (Change to other color) and the least discoloration was found with UP $\left(\Delta \mathrm{E}^{*}{ }_{\mathrm{DW}}=0.41\right)$ (extremely slight change) after immersion in DW. After aging treatment only DL showed color change to other color (Table 4).

The liner materials were compared with ANOVA and then pairwise comparisons were done by using

Table 1. Properties of the liner materials used in this study.

\begin{tabular}{|c|c|c|c|c|c|c|c|}
\hline Material & Code & Type & Composition & $\begin{array}{l}\text { Usage } \\
\text { Period }\end{array}$ & Batch No. & $\begin{array}{c}\text { Curing } \\
\text { Procedure }\end{array}$ & Manufacturer \\
\hline Dura-Liner II & DL & $\begin{array}{l}\text { Acrylic Based } \\
\text { Hard Liner } \\
\text { Material } \\
\text { Cold curing }\end{array}$ & $\begin{array}{c}\text { P: poly (ethyl } \\
\text { methacrylate) } \\
\text { L: butylmethacrylate }\end{array}$ & Permanent & $\begin{array}{l}\text { P: } 081100 \\
\text { L: } 0102300\end{array}$ & $\begin{array}{c}12 \text { minute } \\
\text { at room } \\
\text { temperature in } \\
\text { teflon mould }\end{array}$ & $\begin{array}{c}\text { Dental Mfg. Co Il- } \\
\text { linois, USA }\end{array}$ \\
\hline $\begin{array}{l}\text { Tokuso } \\
\text { Rebase }\end{array}$ & TR & $\begin{array}{l}\text { Acrylic Based } \\
\text { Hard Liner } \\
\text { Material } \\
\text { Cold curing }\end{array}$ & $\begin{array}{c}\text { P: poly lethyl } \\
\text { methacrylate) } \\
\text { L: a-methacryloyl } \\
\text { oxyethyl propionate } \\
\text { 1,6-hexanediol } \\
\text { dimethacrylate }\end{array}$ & Permanent & $557561 \mathrm{E}$ & $\begin{array}{l}8 \text { minute at } \\
\text { room } \\
\text { temperature in } \\
\text { teflon mould }\end{array}$ & $\begin{array}{c}\text { Tokuyama Corp. } \\
\text { Tokyo, Japan }\end{array}$ \\
\hline $\begin{array}{l}\text { Ufi Gel } \\
\text { Hard }\end{array}$ & UH & $\begin{array}{l}\text { Acrylic Based } \\
\text { Hard Liner } \\
\text { Material } \\
\text { Cold curing }\end{array}$ & $\begin{array}{c}\text { P: poly acrylate } \\
\text { L: HEDMA }\end{array}$ & Permanent & 0240.01 & $\begin{array}{l}7 \text { min at room } \\
\text { temperature in } \\
\text { teflon mould }\end{array}$ & $\begin{array}{c}\text { Voco, Cuxhaven, } \\
\text { Germany }\end{array}$ \\
\hline Molloplast B & MP & $\begin{array}{c}\text { Silicone Based } \\
\text { Soft Liner } \\
\text { Material } \\
\text { Heat curing }\end{array}$ & $\begin{array}{l}\text { Paste: } \\
\text { gama-methacryloxy } \\
\text { propyl trimethoxy silan, } \\
\text { polydimethyl siloxane }\end{array}$ & Permanent & 020525 & $\begin{array}{c}15 \text { minute at } \\
200 \mathrm{~kg} / \mathrm{cm} 2 \\
\text { pressure in } \\
\text { flask, placed } \\
\text { in cold water } \\
\text { and then } \\
\text { heated slowly } \\
\text { to } 100^{\circ} \mathrm{C} \text { for } 2 \\
\text { hours }\end{array}$ & $\begin{array}{c}\text { Detax Ettlingen, } \\
\text { Germany }\end{array}$ \\
\hline $\begin{array}{l}\text { Ufi Gel } \\
\text { Permanent }\end{array}$ & UP & $\begin{array}{l}\text { Silicone Based } \\
\text { Soft Liner } \\
\text { Material } \\
\text { Cold curing }\end{array}$ & $\begin{array}{c}\text { B:modified } \\
\text { polydimethylsiloxane } \\
\text { C: platinum } \\
\text { catalyst }\end{array}$ & Permanent & 300.185 & $\begin{array}{c}12 \text { minute } \\
\text { at room } \\
\text { temperature in } \\
\text { teflon mould }\end{array}$ & $\begin{array}{c}\text { Voco, Cuxhaven, } \\
\text { Germany }\end{array}$ \\
\hline
\end{tabular}


Kruskal-Wallis nonparametric tests. The results of ANOVA and pairwise comparisons indicated that there were significant differences among the materials after immersion in DW lexcept UP and $\mathrm{DL}$; MP and TR) (for dw $\mathrm{H}=25.455$; $\mathrm{P}<$.001) and after aging (except UP and MP) (for aging $\mathrm{H}=25.974$; $P<.001$ ) (Table 5).

The effects of treatments dependent to each material were examined by using Mann-Whitney $U$ tests (Tables 6 and 7). As seen in Table 6, the most discoloring treatment was aging $\left(\Delta \mathrm{E}^{*}{ }_{\mathrm{DL}}=16.30\right.$, $\mathrm{P}=.004)$ and the least discoloring treatment was $D W\left(\Delta E^{*} U P=0.41, P=.004\right)$. Comparisons between these two treatments showed that there were differences in samples of UP, DL, MP, and TR, but indifferences in samples of UH after immersion in DW and aging.

Control and aging groups were compared based on materials by using two-independentsamples Mann-Whitney U tests (Table 7). Comparisons between these two subgroups showed that there were not differences in samples of acrylic and silicone based liner materials after immersion in DW, but differences in them after aging.

Table 2. NBS rating.

\begin{tabular}{lc}
\hline NBS unit & $\begin{array}{c}\text { Critical Remarks Of Color } \\
\text { Differences }\end{array}$ \\
\hline $0.0 \sim 0.5$ & Extremely slight change \\
$0.5 \sim 1.5$ & Slight change \\
$1.5 \sim 3.0$ & Perceivable change \\
$3.0 \sim 6.0$ & Marked change \\
$6.0 \sim 12.0$ & Extremely marked change \\
12.0 or more & Change to other color \\
\hline
\end{tabular}

\section{DISCUSSION}

The color instability of the lining materials that may affect the patient's acceptance, have often been reported in clinical studies and may lead to a clinical decision to replace the lining. ${ }^{32,33}$ Even though the properties of lining materials have been much improved, they still have disadvantages including water sorption, solubility and obvious color changes. ${ }^{34}$ The best liner materials available today do not demonstrate an extended service life of more than a few years. ${ }^{6,22}$

The technology for dental color matching has changed over the past several decades. In the previous studies, colorimeter measurements have been compared with spectrophotometer readings and deemed as reliable and accurate as spectrophotometer for color difference measurements. ${ }^{23,35}$ The colorimeter used in this study is new, easy to use, portable, offers accurate measurements, the spectral range is $380-730 \mathrm{~nm}$ and for illumination it uses D65 gas filled tungsten.

CIELAB color space is commonly used in perceptual studies and dental color assessment because of its uniform coverage of the color space. In this system there are three coordinates: $L^{*}$, $a^{*}, b^{*} . L^{*}$ indicates lightness, which ranges from 0 (black) to 100 (white). The quantities $a^{*}$ and $b^{*}$ are chromacity coordinates that indicate color directions: positive $a^{*}$ corresponds to red direction, whereas negative $a^{*}$ indicates the green direction; positive and negative $b^{*}$ values correspond to yellow and blue directions, respectively. ${ }^{20,35,36}$ In the present study, $a^{*}$ values of the tested materials' decreased (to green) either after aging or immersion in DW (except MP after immersion in DW). L*

Table 3. Color of the liner materials before and after treatments.

\begin{tabular}{|c|c|c|c|c|c|c|c|c|c|c|c|c|c|}
\hline \multicolumn{2}{|c|}{ Material } & \multicolumn{3}{|c|}{$\begin{array}{l}\text { Before immersion } \\
\text { in DW }\end{array}$} & \multicolumn{3}{|c|}{$\begin{array}{c}\text { After immersion } \\
\text { in DW }\end{array}$} & \multicolumn{3}{|c|}{ Before aging } & \multicolumn{3}{|c|}{ After aging } \\
\hline & & $L^{*}$ & $a^{*}$ & $b^{*}$ & $\mathrm{~L}^{*}$ & $a^{*}$ & $b^{*}$ & $\mathrm{~L}^{*}$ & $a^{*}$ & $b^{*}$ & $\mathrm{~L}^{*}$ & $a^{*}$ & $b^{*}$ \\
\hline \multirow[t]{2}{*}{ DL } & Mean & 47.35 & 15.99 & 8.00 & 47.39 & 15.69 & 7.93 & 52.31 & 16.28 & 7.93 & 58.69 & 7.99 & 16.50 \\
\hline & SD & 0.81 & 0.30 & 0.26 & 0.99 & 0.62 & 0.27 & 1.57 & 0.30 & 0.27 & 8.02 & 3.80 & 4.69 \\
\hline \multirow[t]{2}{*}{ TR } & Mean & 39.92 & 20.06 & 6.24 & 40.06 & 19.11 & 6.40 & 39.72 & 24.22 & 7.15 & 42.36 & 12.09 & 8.07 \\
\hline & SD & 2.48 & 1.47 & 0.49 & 2.47 & 1.65 & 0.63 & 0.71 & 0.72 & 0.45 & 1.92 & 1.92 & 3.25 \\
\hline \multirow[t]{2}{*}{ UH } & Mean & 56.50 & 9.37 & 12.25 & 53.78 & 9.36 & 18.47 & 48.00 & 12.43 & 17.66 & 42.25 & 12.16 & 24.05 \\
\hline & SD & 1.03 & 0.33 & 0.70 & 2.42 & 0.62 & 2.18 & 0.91 & 0.83 & 0.39 & 0.60 & 0.42 & 1.75 \\
\hline \multirow[t]{2}{*}{ MP } & Mean & 47.08 & 12.49 & 11.68 & 46.74 & 13.30 & 13.02 & 47.11 & 13.38 & 11.38 & 43.81 & 11.65 & 13.92 \\
\hline & SD & 0.97 & 0.81 & 1.41 & 0.81 & 0.55 & 1.11 & 0.95 & 0.77 & 0.60 & 0.82 & 0.56 & 1.42 \\
\hline \multirow[t]{2}{*}{ UP } & Mean & 42.78 & 17.15 & 2.94 & 42.99 & 17.00 & 3.16 & 44.75 & 16.21 & 2.89 & 43.30 & 15.83 & 5.75 \\
\hline & SD & 0.17 & 0.29 & 0.18 & 0.27 & 0.16 & 0.16 & 0.90 & 0.57 & 0.85 & 1.09 & 0.35 & 1.16 \\
\hline
\end{tabular}


values of all the tested materials' lexcept UH and MP) increased (to white) after immersion in DW, while these values (except DL and TR) decreased (to black) after aging. b* values of the materials' (except DL after immersion in DW) increased (to yellow) both after immersion in DW and aging.

The National Bureau of Standards (NBS) established a rating system to describe color differences by NBS units. ${ }^{20} \Delta \mathrm{E}^{*}$ values of this in vitro study were converted to NBS units to facilitate comparison with clinical studies. According to the NBS units; DL showed change to other color $\left(\Delta E^{*}{ }_{D L}=16.30\right)$, while UP and MP revealed marked change $\left(\Delta E^{*}{ }_{U P}=3.46, \Delta E^{*}{ }_{M P}=4.78\right)$ after aging. As a result, UP showed the highest color stability after immersion in DW and aging. This property may be of advantage to its long-term serviceability in severe oral cavity environment.

An accelerated aging process has been used in this study in order to simulate the oral environment. Even if the oral environment is more complex, this aging treatment is still useful for the comparison of different lining materials as the closest simulation of oral environment. ${ }^{17}$ It has been reported that water spray and visible ultra- violet light have a direct effect on the properties of liners and cause them to swell. ${ }^{19}$ The changes that may occur in polymers as a result of this process are; scission of the polymer chains by UV light, oxygen cross-linking, leaching of plasticizers and absorption of water. ${ }^{37}$

Previous studies have shown the effectiveness of accelerated aging in evaluating the color stability of soft denture liners. ${ }^{17,22}$ Similarly, in the current study, significant color changes were seen in all of the tested materials after aging.

The clinical color stability behavior or performance of acrylic and silicone based lining materials would be different due to their different structures. ${ }^{38}$ Water sorption and solubility can dramatically affect stain resistance, dimensional stability, physical and mechanical properties. ${ }^{6}$ When immersed in saliva during clinical use and may be soaked in water or cleansing agents when not in use; plasticizers and other soluble may leach out over extended periods while water is absorbed until equilibrium is reached. ${ }^{16}$ At 1 week, water sorption value should not be more than 0.8 $\mathrm{mg} / \mathrm{cm}^{2}$ and the solubility should not be more than $0.04 \mathrm{mg} / \mathrm{cm}^{2}$ for different liners. ${ }^{27}$ Water sorption

Table 4. Color changes of the liner materials.

\begin{tabular}{lcccc}
\hline Material & Treatment & Mean $\Delta \mathrm{E}^{*}$ & $\mathrm{SD}$ & NBS unit \\
\hline $\mathrm{DL}$ & Immersion in DW & 0.50 & 0.18 & 0.46 \\
& Aging & 16.30 & 3.25 & 14.99 \\
TR & Immersion in DW & 1.19 & 0.70 & 1.10 \\
& Aging & 13.01 & 1.37 & 11.96 \\
UH & Immersion in DW & 7.13 & 0.62 & 6.56 \\
& Aging & 8.68 & 2.12 & 7.99 \\
MP & Immersion in DW & 1.75 & 1.07 & 1.61 \\
& Aging & 4.78 & 1.05 & 4.39 \\
UP & Immersion in DW & 0.41 & 0.11 & 0.38 \\
& Aging & 3.46 & 1.23 & 3.18 \\
\hline
\end{tabular}

$\triangle \mathrm{E}^{*}$ : Color Change Value SD: Standard Deviation NBS UNIT: National Bureau of Standards Unit

Table 5. Kruskal-Wallis non-parametric test results of the liner materials.

\begin{tabular}{|c|c|c|c|c|c|c|}
\hline \multirow{4}{*}{ Immersion in DW } & & UP & $\mathrm{DL}$ & TR & MP & $\mathrm{UH}$ \\
\hline & Mean $\Delta \mathrm{E}^{*}$ & 0.41 & 0.50 & 1.19 & 1.75 & 7.13 \\
\hline & Mean rank & 5.33 & 8.33 & 17.00 & 19.33 & 27.50 \\
\hline & & \multicolumn{2}{|c|}{ Kruskal-Wallis H=25.455 } & \multicolumn{2}{|c|}{$\mathrm{P}<.001$} & \\
\hline \multirow{4}{*}{ Aging } & & UP & MP & $\mathrm{UH}$ & TR & DL \\
\hline & Mean $\Delta \mathrm{E}^{*}$ & 3.46 & 4.78 & 8.68 & 13.01 & 16.30 \\
\hline & Mean rank & 4.67 & 8.50 & 15.50 & 22.17 & 26.67 \\
\hline & & Kruska & $\bar{y}=25.9$ & \multicolumn{2}{|c|}{$P<.001$} & \\
\hline
\end{tabular}

Lines connect values that were not significantly different at the $\mathrm{P}<.001$ level. 
depends on the degree of hydrophobicity and porosity of the liner. ${ }^{3}$ Acrylic resin liners have high water sorption and solubility. On the other hand, silicon liners considered to be stable in aqueous environments for variable lengths of time and the hydrophobicity of them reduces water sorption. ${ }^{8,39}$ These liners might be expected to possess more stain resistant than would the acrylic materials tested. Kawano et $a^{6}{ }^{6}$ investigated the sorption and solubility of 12 soft denture liners and reported that MP had sorption values $(0.23 \pm 0.01)$ less than $0.8 \mathrm{mg} / \mathrm{cm}^{2}$ after 1 year and this met the 1 week sorption requirements of ADA specification 12. In the current study, MP had low color change value after immersion in $\mathrm{DW}\left(\Delta \mathrm{E}^{*}=1.75\right)$ and after aging $\left(\Delta E^{*}=4.78\right)$. This result might be attributed to the low sorption values of MP. Shotwell et $\mathrm{al}^{22}$ investigated the color stability of long term soft liners after accelerated aging and showed the appreciable (marked change) NBS unit of MP (NBS unit, 3.3). Anil et al ${ }^{12}$ compared the color stability of five denture reline materials and found the lower NBS unit of MP (NBS unit, 1.94) than TR (NBS unit, 3.8) and UP (NBS unit, 56.05). However, UP was the most color stable liner material in this study (NBS unit, 3.18) and TR showed extremely marked change (NBS unit, 11.96) after aging. The differ- ences in color measurements of these two studies might be explained by the variations in the properties of the instruments used. This effect should be kept in mind while comparing the results of the researches about the color stability.

In the present study, acrylic and silicone based liners exhibited significantly different color change values after aging. Silicone based liners (UP, MP) seemed to be more resistant to staining than acrylic based liners (UH, TR, DL). Furthermore, comparing acrylic based liners, UH showed marked change than the other acrylic based liners (TR, DL) after immersion in DW. This might lead us to associate this result with the chemical composition of UH, porosity formed by the air inclusions during mixing powder and liquid, surface roughness and water absorption.

Color stability of these materials may vary depending on their monomers' chemical composition. ${ }^{34}$ Residual monomer is a well-known plasticizer which remains in polymerized resin as free or unreacted monomer and it affects physical and mechanical properties of acrylics. ${ }^{40}$ According to the previous research by Urban et al, 40,41 comparisons between the residual monomer in hard acrylic relining resins (DL, TR, UH, Kooliner) and heat-polymerized denture base resin (Lucitone

Table 6. Mann-Whitney $U$ test results of the liner materials.

\begin{tabular}{|c|c|c|c|c|c|c|}
\hline \multirow[b]{2}{*}{ Material } & \multicolumn{2}{|c|}{ Immersion in DW } & \multicolumn{2}{|c|}{ Aging } & \multirow[b]{2}{*}{ Mann-Whitney U } & \multirow[b]{2}{*}{ Significance } \\
\hline & Mean $\Delta \mathrm{E}^{*}$ & Mean rank & Mean $\Delta E^{*}$ & Mean rank & & \\
\hline $\mathrm{DL}$ & 0.50 & 3.50 & 16.30 & 9.50 & 0.000 & $P=.004$ \\
\hline TR & 1.19 & 3.50 & 13.01 & 9.50 & 0.000 & $P=.004$ \\
\hline UH & 7.13 & 4.50 & 8.68 & 8.50 & 6.000 & $P=.055$ \\
\hline MP & 1.75 & 3.67 & 4.78 & 9.33 & 1.000 & $P=.006$ \\
\hline UP & 0.41 & 3.50 & 3.46 & 9.50 & 0.000 & $P=.004$ \\
\hline
\end{tabular}

$n=6, P<.01$

Table 7. Mann-Whitney $U$ test results of acrylic and silicone based denture liner materials.

\begin{tabular}{|c|c|c|c|c|}
\hline Treatment & $\begin{array}{c}\text { Acrylic based liner } \\
\text { materials }\end{array}$ & $\begin{array}{c}\text { Silicone based liner } \\
\text { materials }\end{array}$ & Mann-Whitney U & Significance \\
\hline $\begin{array}{l}\text { Immersion in DW } \\
\text { (Mean rank) }\end{array}$ & 17.61 & 12.33 & 70.000 & $P=.108$ \\
\hline $\begin{array}{l}\text { Aging } \\
\text { (Mean rank) }\end{array}$ & 21.44 & 6.58 & 1.000 & $P<.001$ \\
\hline
\end{tabular}


$550)$ in $55^{\circ} \mathrm{C}$ water bath resulted in an arrangement as Kooliner $(1.52 \%)>\mathrm{DL}(0.85 \%)>\mathrm{UH}$ $(0.45 \%)>$ Lucitone $550(0.24 \%)>$ TR $(0.14 \%)$. In the present study, DL showed poor color stability after aging $\left(\Delta E^{*}=16.30\right)$. This result might be related to the amount of leaching residual monomer with color stability.

Several studies have been done about the color measurements by using colorimeters ${ }^{21,22}$ and usually these studies have been compared directly. The present results cannot be compared directly with previous studies because of the variations in the instruments used, sample sizes and conditioning of the samples. Although the system of color change is not known exactly, it could be guessed by investigating how aging changes the physical and mechanical properties of denture liners. ${ }^{17,19}$

Test conditions used for in vitro studies do not subject the materials to the aqueous environment, microorganisms, abrasion, thermocycling, material thickness and cyclic loading. The properties of liner materials in the clinical situations still differ from laboratory testing. ${ }^{42}$ There also seems to be a need for extra researches to understand the effect of aging on color change mechanism.

\section{CONCLUSIONS}

- Accelerated aging affected color stability of all the materials tested.

- The measurements showed that UP and MP are clinically reliable denture liner materials.

- From a clinical aspect, for long-term clinical serviceability, it seems reasonable to recommend the use of silicone based instead of acrylic based liner materials.

\section{REFERENCES}

1. Fujii K, Arikawa H, Kanie T, Shinohara N, Inoue K. Effect of photo-irradiation on hardness of soft lining materials for denture base. J Oral Rehabil 2002;29:744-748.

2. Minami H, Suzuki S, Ohashi H, Kurashige H, Tanaka T. Effect of surface treatment on the bonding of an autopolymerizing soft denture liner to a denture base resin. Int $J$ Prosthodont 2004;17:297-301.

3. Hayakawa I, Keh ES, Morizawa M, Muraoka G, Hirano S. A new polyisoprene-based light-curing denture soft lining material. J Dent 2003;31:269-274.

4. Garcia RM, Leon BT, Oliveira VB, Del Bel Cury AA. Effect of a denture cleanser on weight, surface roughness and tensile bond strength of two resilient denture liners. J Prosthet
Dent 2003;89:489-494.

5. Garcia LT, Jones JD. Soft liners. Dent Clin North Am 2004;48:709-720.

6. Kawano F, Dootz ER, Koran III A, Craig RG. Sorption and solubility of 12 soft denture liners. J Prosthet Dent 1994;72:393398.

7. Pinto JR, Mesquita MF, Henriques GE, de Arruda Nobilo MA. Effect of thermocycling on bond strength and elasticity of 4 long-term soft denture liners. $J$ Prosthet Dent 2002;88:516-521.

8. Walters MGJ, Jagger RG, Polyzois GL. Wettability of silicone rubber maxillofacial prosthetic materials. J Prosthet Dent 1999;81:439-443.

9. Polyzois GL, Frangou MJ. Influence of curing method, sealer, and water storage on the hardness of a soft lining material over time. J Prosthodont 2001;10:42-45.

10. Haywood J, Basker RM, Watson CJ, Wood DJ. A comparison of three hard chairside denture reline materials. Clinical evaluation. Eur J Prosthodont Restor Dent 2003;11:157163.

11. Parr GR, Rueggeberg FA. In vitro hardness, water sorption, and resin solubility of laboratory-processed and autopolymerized long-term resilient denture liners over one year of water storage J Prosthet Dent 2002;88:139-144.

12. Anil N, Hekimoglu C, Sahin S. The effect of accelerated aging on color stability of denture liners. JOral Sci 1998;3:105108.

13. Al-Athel M, Jagger $R$, Jagger $D$. Effect of ageing on the bond strength of a permanent denture soft lining material. J Oral Rehabil 2002;29:992-996.

14. El-Hadary A, Drummond JL. Comparative study of water sorption, solubility, and tensile bond strength of two soft lining materials. J Prosthet Dent 2000;83:356-361.

15. Anil N, Hekimoglu C, Buyukbas N, Ercan MT. Microleakage study of various soft denture liners by autoradiography: Effect of accelerated aging. J Prosthet Dent 2000; 84:394-399.

16. Leon BL, Del Bel Cury AA, Rodrigues Garcia RC. Water sorption, solubility, and tensile bond strength of resilient denture lining materials polymerized by different methods after thermal cycling. J Prosthet Dent 2005;93:282-287.

17. Anil N, Hekimoglu C, Sahin S. Color stability of heat-polymerized and auto-polymerized soft denture liners. J Prosthet Dent 1999;81:481-484.

18. Jin C, Nikawa H, Makihira S, Hamada T, Furukawa M, Murata $\mathrm{H}$. Changes in surface roughness and colour stability of soft denture lining materials caused by denture cleansers. J Oral Rehabil 2003;30:125-130.

19. Kawano F, Koran A, Nuryanti A, Inoue S. Impact absorption of four processed soft denture liners as influenced by accelerated aging. Int J Prosthodont 1997;10:55-60. 
20. Ergün G, Mutlu-Sagesen L, Özkan Y, Demirel E. In vitro color stability of provisional crown and bridge restoration materials. Dent Mater J 2005;24:342-350.

21. Saygili G, Sahmali S, Demirel F. Color stability of porcelain repair materials with accelerated ageing. $J$ Oral Rehabil 2006;33:387-392.

22. Shotwell JL, Razzoog ME, Koran A. Color stability of longterm soft denture liners. J Prosthet Dent 1992; 68:836-838.

23. Tung FF, Goldstein GR, Jang S, Hittelman E. The repeatability of an intraoral dental colorimeter. $J$ Prosthet Dent 2002;88:585-590.

24. Mutlu-Sagesen L, Ergün G, Özkan Y, Semiz M. Color stability of a dental composite after immersion in various media. Dent Mater J 2005;24:382-390.

25. Okubo SR, Kanawati A, Richards MW, Childress S. Evaluation of visual and instrument shade matching. $J$ Prosthet Dent 1998;80:642-648.

26. Mutlu-Sagesen L, Ergun G, Özkan Y, Bek B. Color stability of different denture teeth materials: an in vitro study. $J$ Oral Sci 2001;43:193-205.

27. ADA American Dental Association Council on Dental Materials and Devices: Specification No. 12: Denture Base Polymers. Chicago, IL, 1975:90.

28. Craig RG, Powers JM. Restorative Dental Materials. 11th ed, St. Louis: Mosby Co, 2002: 667

29. Douglas RD. Color stability of new-generation indirect resins for prosthodontic application. $J$ Prosthet Dent 2000;83:166-170.

30. Cal E, Guneri P, Kose T. Comparison of digital and spectrophotometric measurements of colour shade guides. $J$ Oral Rehabil 2006;33:221-228.

31. Korkmaz T, Ergun G, Yılmaz C, Özkan Y. Color stability of glazed and polished dental porcelains. Int Dent $J$ 2000;6:333-334.

32. Braden M, Wright PS, Parker S. Soft lining materials-a review. Eur J Prosthodont Restor Dent 1995;3:163-174.

33. Polyzois GL, Yannikakis SA, Zissis AJ. Color stability of visible light-cured, hard direct denture reliners: an in vitro investigation. Int J Prosthodont 1999;12:140-146.

34. Hayakawa I, Akiba N, Keh E, Kasuga Y. Physical properties of a new denture lining material containing a fluoroalkyl methacrylate polymer. J Prosthet Dent 2006; 96:53-58.

35. Analoui M, Papkosta E, Cochran M, Matis B. Designing visually optimal shade guides. $J$ Prosthet Dent 2004;92:371376.

36. Ergün G, Doḡan OM, Özkan Y, Demirel E, Doḡan A. Color stability of denture base materials after soaked in different aging solutions. Balk J Stom 2000;4:93-97.

37. Wagner WC, Kawano F, Dootz ER, Koran A. Dynamic viscoelastic properties of processed soft denture liners: Part
I- Initial properties. J Prosthet Dent 1995;73:471-477.

38. Hekimoḡlu C, Anil N. The effect of accelerated ageing on the mechanical properties of soft denture lining materials. J Oral Rehabil 1999;26:745-748.

39. Yoeli Z, Miller V, Zeltser C. Consistency and softness of soft liners. J Prosthet Dent 1996;75:412-418.

40. Urban VM, Cass QB, Oliveira RV, Giampaolo ET, Machado AL. Development and application of methods for determination of residual monomer in dental acrylic resins using high performance liquid chromatography. Biomed Chromatogr 2006;20:369-376.

41. Urban VM, Machado AL, Oliveira RV, Vergani CE, Pavarina AC, Cass QB. Residual monomer of reline acrylic resins effect of water-bath and microwave post-polymerization treatments. Dent Mater 2007;23:363-368.

42. Kiat-Amnuay S, Gettleman L, Mekayarajjananonth T, Khan $Z$, Goldsmith LJ. The influence of water storage on durometer hardness of 5 soft denture liners over time. J Prosthodont 2005;14:19-24. 